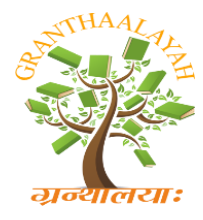

INTERNATIONAL JOURNAL OF RESEARCH GRANTHAALAYAH A knowledge Repository

Science

\title{
HELMINTH PARASITES OF THE SUBDESERT TOAD, AMIETOPHRYNUS (BUFO) XEROS (ANURA: BUFONIDAE)
}

\author{
Yassir Sulieman*1, Azzam Afifi' ${ }^{2}$, Higazi M. Awad ${ }^{3}$, Theerakamol Pengsakul ${ }^{4}$ \\ ${ }^{1}$ Department of Zoology, Faculty of Science and Technology, University of Shendi, SUDAN \\ ${ }^{2}$ Department of Zoology, Faculty of Science and Technology, Omdurman Islamic University, \\ SUDAN \\ ${ }^{3}$ Faculty of Nursing Sciences, University of Shendi, SUDAN \\ ${ }^{4}$ Faculty of Medical Technology, Prince of Songkla University, Hat Yai, Songkhla 90110, \\ THAILAND
}

\begin{abstract}
Sixty-nine subdesert toads, Amietophrynus (Bufo) xeros, were collected in Shendi, Sudan, from August to November 2014, and examined for the first time for the presence of internal helminth parasites. Sixty-seven (97.1\%) of the toads were found infected with one or more helminth species including, four Nematoda: Aplectana macintoshii, Rhabdias bufonis, Strongyloides prokopici, and Oswaldocruzia sp.; one Trematoda: Mesocoelium sp.; one Cestoda: Lanfrediella sp. A higher prevalence and intensity of infection was found in male toads compared with females, and old toads were found to harbor a higher prevalence and intensity of infection when compared to younger ones. However, neither of these differences was statistically significant. In addition, there were no significant correlations found between the gender of the toads examined and either the prevalence or intensity of infection of any of the helminth species. Likewise, the prevalence and intensity of infection of the helminth species were not significantly correlated with the snout-vent length of the toads.
\end{abstract}

Keywords:

Amietophrynus (Bufo) xeros; Helminth parasites; Prevalence; Intensity; Sudan.

Cite This Article: Yassir Sulieman, Azzam Afifi, Higazi M. Awad, and Theerakamol Pengsakul, "HELMINTH PARASITES OF THE SUBDESERT TOAD, AMIETOPHRYNUS (BUFO) XEROS (ANURA: BUFONIDAE)" International Journal of Research - Granthaalayah, Vol. 3, No. 10(2015): 75-83. DOI: https://doi.org/10.29121/granthaalayah.v3.i10.2015.2934.

\section{INTRODUCTION}

The subdesert toad, Amietophrynus (Bufo) xeros is a terrestrial Anura, lives in arid regions of Africa close to permanent water bodies, dry riverbeds and around oases (Rödel, 2000; Harper et al., 2010). This species has been classified as least concern, according to the International Union for the Conservation of Nature Red List criteria (IUCN, 2013). Within Sudan, A. xeros is found in 
the northern parts; inhabits local farms, gardens and orchards, and is well adapted to anthropogenic areas. It is mainly nocturnal and feeds on small invertebrates such as spiders, beetles and other insects. It is well known that amphibians have a rich parasite fauna, including viruses, protozoans and helminths (Canning et al., 1964; Hyatt et al., 2000; Duszynski et al., 2007; Rahman et al., 2008; Sulieman and Pengsakul, 2015). Several studies have been carried out on the protozoan and helminth parasites of Amphibia (Mcallister et al., 1995; Dare et al., 2008; Santos et al., 2013). However, to date, no studies exist on the parasite fauna of A. xeros. Therefore, the present study will provide a baseline of information on the following: (i) the helminth parasites of this toad species in Shendi, a city located in the northern part of Sudan (ii) the prevalence and intensity of helminth infections in relative to the toads' age and gender.

\section{MATERIALS AND METHODS}

From August to November 2014, 69 A. xeros toads were collected manually from the agricultural lands and orchards in Shendi $\left(16^{\circ} 40^{\prime} \mathrm{N}, 33^{\circ} 25^{\prime} \mathrm{E}\right)$, Sudan. The specimens were immediately transferred to the Laboratory of Zoology, University of Shendi, and sacrificed using chloroform. The snout-vent length (SVL) and gender were recorded for each individual. The hosts were grouped into two age classes on the basis of their SVL (juveniles: < $40 \mathrm{~mm}$, and adults: $40-80 \mathrm{~mm}$ ) based on the observation that individuals with a SVL below 40mm did not have differentiated gonads. In the necropsy, the internal organs: lungs, heart, liver, esophagus, stomach, small intestine, large intestine, urinary bladder and kidneys were removed, dissected and placed in separate petri-dishes containing $0.9 \%$ normal saline solution and examined thoroughly under a stereomicroscope for helminth parasite infections. The helminth isolated were prepared following Leon-Regagnon et al. (2005), then identified under a compound microscope based on the works of Baker and Vaucher (1986), Melo et al. (2011) and Calhoun and Dronen (2012). The prevalence and intensity of infections were calculated in accordance with Bush et al. (1997). The SPSS 16.0 analytical software was used for the statistical analysis. The relationship of the prevalence and intensity of infection to host gender and SVL were calculated using Pearson correlation coefficients ( $r$ ) and paired sample tests were used to compare the intensity and prevalence of infection based on the specimens' gender and age (according to SVL). The helminth specimens were preserved in 70\% ethanol and deposited in the Department of Zoology, Faculty of Science and Technology, University of Shendi.

\section{RESULTS}

Out of the 69 A. xeros collected, 67 (97.1\%) specimens were found infected with one or more internal helminth parasite species of either nematode or platyhelminth or both. Six different helminth species were recovered from the internal organs of the toads examined including, Nematoda: Aplectana macintoshii, Rhabdias bufonis, Strongyloides prokopici, and Oswaldocruzia sp.; Trematoda: Mesocoelium sp.; Cestoda: Lanfrediella sp. The prevalence, mean intensity and site of infection of these helminths identified were given in table1. Of the 69 specimens examined, $29(42.03 \%)$ harbored one species, $25(36.23 \%)$ harbored two species, $12(17.40 \%)$ harbored three species, and one $(1.45 \%)$ harbored four species.

There was no significant correlation found between the gender of the toads examined and either the, prevalence or intensity of infection of any of the helminth species $(\mathrm{r}=-0.03$ to $0.13, \mathrm{P}=0.17$ 
to 0.98). Likewise, the prevalence and intensity of helminth species were not significantly correlated with the SVL of the toad species $(r=-0.01$ to $0.20, P=0.08$ to 0.96$)$.

A relatively high prevalence of infections was observed among male toads compared with females (Fig. 1), although this difference was not statistically significant $(\mathrm{P}=0.86)$. Likewise, a high prevalence was observed among old toads (SVL 40-80 $\mathrm{mm}$ ) when compared with younger ones (SVL $<40 \mathrm{~mm}),($ Fig. 2), but this difference was not statistically significant $(\mathrm{P}=0.12)$. Similarly, a high intensity of infections was observed among male toads compared with females (Fig. 3), however, the difference was not statistically significant $(\mathrm{P}=0.27)$. Finally, old toads harbored a higher intensity of infections than younger ones (Fig. 4), but again, the difference was not statistically significant $(\mathrm{P}=0.59)$.

\section{DISCUSSION}

In the present study, six helminth taxa were recorded from the subdesert toad, A. xeros including, Nematoda: Aplectana macintoshii, Rhabdias bufonis, Strongyloides prokopici and Oswaldocruzia sp.; Trematoda: Mesocoelium sp.; Cestoda: Lanfrediella sp. All of the helminths identified have previously been reported to parasitize several anuran species (Baker, 1987; Kuzmin et al., 2007; Dronen et al., 2012). However, no previous studies exist regarding the parasite fauna of the toad, A. xeros. The nematode, Aplectana macintoshii was the most common parasite found to be harbored by A. xeros in this study. This species belongs to the family Cosmocercidae, which includes approximately 41 species and the majority of which parasitize the intestine of frogs and toads; those species are found in North America, Europe, Asia, South America and Africa (Baker, 1980; Adamson and Baccam, 1988). The genus Strongyloides is usually an intestinal parasite of vertebrates, but has previously been reported as infecting amphibians (Moravec et al., 1987; Patterson-Kane et al., 2001). Likewise, the genus Oswaldocruzia, family Molineidae is a cosmopolitan parasite of amphibians and reptiles (Ben Slimane and Durette-Desset, 1996). The genus Rhabdias, family Rhabdiasidae is a parasite in the lungs of amphibians and reptiles (Baker, 1987). It is cosmopolitan in distribution and lives in any environment that supports its host frog and toad species (Goater, 1992). The cestode Lanfrediella, is a new genus belonging to the family Nematotaeniidae, and it has been reported from the intestine of the toad Rhinella marina (Melo et al., 2011). The trematode genus, Mesocoelium, belongs to the family Mesocoeliidae, which contains a total of 49 species widely parasitizing amphibians, reptiles and fish (Dronen et al., 2012).

In the present study, the main group of helminths found parasitizing A. xeros were nematode species; this result is consistent with several previous findings on the toads, Bufo ictericus (Luque et al., 2005), Amietophrynus regularis (Ibrahim, 2008) and Rhinella icterica (Santos et al., 2013). This is because, on land, anurans are more exposed to nematodes with monoxenous life cycles such as Strongyloides spp., Rhabdias spp., and cosmocercids, because the majority of nematodes infect anurans through cutaneous penetration or the ingestion of eggs. Similarly, previous studies have shown that the bufonid amphibians tend to harbor a higher number of nematode species than trematodes, as was seen in this study (Bolek and Coggins, 2003), this is likely to be because the terrestrial toads predominantly feed on ants, beetles and other terrestrial invertebrates (Hirai and Matsui, 2002) and are therefore less prone to infection from the wide range of species of trematodes which commonly infect aquatic amphibians. Additionally, it has been reported that 
there is a greater incidence of infection of anurans with nematodes than with cestodes infections (Mohammad, 2010).

A high prevalence and intensity of infection was observed among old male toads in the present study. However, previous studies carried out on anurans found no relationship between the gender of the host and the parasite community structure (Santos and Amato, 2010; Santos et al., 2013). Some studies have documented a decrease in the prevalence of parasite infections according to host age (Ibrahim, 2008; Tinsley et al., 2012), while others have reported no relationship with age (Garvin et al., 2003; Hasselquist et al., 2007). No significant correlations were found between gender and either the prevalence or intensity of infection with any helminth species in this study. Likewise, the prevalence and intensity of helminth infection were not significantly correlated with the SVL of the host toads. However, it has previously been reported that the prevalence of parasitic infections is correlated with the SVL of the water frog Pelophylax kl. Hispanicus (Comas et al., 2014), and there have also been some other same findings of host/parasite relationships (Haas et al., 2012; Treml et al., 2012). An increase in prevalence with age may be caused by prolonged exposure to parasite accumulation (Sanchis et al., 2000). However, some nematode populations diminish in larger hosts, because they become more resistant to new reinfections (Baker, 1979), and have thicker skins protecting them from parasite penetration (Barton, 1998). In addition, other ecological factors may have an influence on the parasite composition of the host.

Finally, this is the first study to establish a list of the helminth parasites that infect the subdesert toad, A. xeros in Sudan. Thus, further studies are required, including studies of their taxonomic aspects.

\section{ACKNOWLEDGEMENTS}

The authors would like to thank Hassan Awad and Abbas Hassan, University of Shendi for their help in the collection of samples.

\section{REFERENCES}

[1] Adamson, M., Baccam, D. 1988. Systematic revision of the Atractidae sensu Chabaud (1978) (Nematoda: Cosmocercoidea): Maracaya belemensis $n . \quad s p$. and Aplectana albaen. sp. from Amphisbaena alba in Brazil. Can. J. Zool. 66: 18571864.

[2] Baker, M.R. 1980. Revision of Old World species of the genus Aplectana Railliet and Henry, 1916 (Nematoda: Cosmocercidae). Bull. Mus. Nat. His. Nat. Paris Ser 4 Sect A. 2: 955-998.

[3] Baker, M.R., Vaucher, C. 1986. Parasitic Helminths from Paraguay XII: Aplectana Railliet and Henry, 1916 (Nematoda: Cosmocercoidea) from Frogs. Rev. Suisse Zool. 93: 607-616.

[4] Baker, M.R. 1979. Seasonal population changes in Rhabdias ranae Walton, 1929 (Nematoda: Rhabdiasidae) in Rana sylvatica of Ontario. Can. J. Zool. 57: 179-193.

[5] Baker, M.R. 1987. Synopsis of the Nematoda parasitic in amphibians and reptiles. Memorial University of Newfoundland, Occas. Pap. Biol. 11: 1-325.

[6] Barton, D.P. 1998. Dynamics of natural infection of Rhabdias cf. hylae (Nematoda) in Bufo marinus (Amphibia) in Australia. Parasitology 117: 505-513. 
[7] Ben Slimane, B., Durette-Desset, M.C. 1996. Four New Species of Oswaldocruzia (Nematoda: Trichostrongylina, Molineoidea) Parasitizing Amphibians and Lizards from Ecuador. Mem. Inst. Oswaldo Cruz., Rio de Janeiro 91: 317-328.

[8] Bolek, M.G., Coggins, J.R. 2003. Helminth community structure of sympatric eastern American toad, Bufo americanus americanus, northern leopard frog, Rana pipiens, and blue-spotted salamander, Ambystoma laterale, from southeastern Wisconsin. J. Parasitol. 89: 673-680.

[9] Bush, A.O., Lafferty, K.D., Lotz, J.M., Shostak, A.W. 1997. Parasitology meets ecology on its own terms: Margolis et al. revisited. J. Parasitol. 83: 575-583.

[10] Calhoun, D.M., Dronen, N.O. 2012. A reevaluation of specimens of Mesocoelium monas (Platyhelminthes: Digenea: Mesocoeliidae) from the Natural History Museum, UK and the United States National Parasite Collection, USA. Zootaxa 3589: 1-29.

[11] Canning, E.U., Elkan, E., Trigg, P.I. 1964. Plistophora myotrophica spec. nov., causing high mortality in the common toad Bufo bufo L., with notes on the maintenance of Bufo and Xenopus in the laboratory. J. Protozool. 11: 157-166.

[12] Comas, M., Ribas, A., Milazzo, C., Sperone, E., Tripepi, S. 2014. High levels of prevalence related to age and body condition: host-parasite interactions in a water frog Pelophylax kl. Hispanicus. Acta Herpetol. 9: 25-31.

[13] Dare, O.K., Nadler, S.A., Forbes, M.R. 2008. Nematode lungworms of two species of anuran amphibians: Evidence for co-adaptation. Int. J. Parasitol. 38: 1729-1736.

[14] Dronen, N.O., Calhoun, D.M., Simcik, S.R. 2012. Mesocoelium Odhner, 1901 (Digenea: Mesocoelidae) revisited; a revision of the family and re-evaluation of species composition in the genus. Zootaxa 3387: 1-96.

[15] Duszynski, D., Bolek, M., Upton, S. 2007. Coccidia (Apicomplexa: Eimeriidae) of Amphibians of the World. Zootaxa 1667: 1-77.

[16] Garvin, M.C., Basbaum, J.P., Ducore, R.M., Bell, K.E. 2003. Patterns of Haemoproteus beckeri parasitism in the gray catbird (Dumetella carolinensis) during the breeding season. J. Wildlife Dis. 39: 582-587.

[17] Goater, C., Ward, P. 1992. Negative Effects of Rhabdias bufonis Nematoda on the Growth and Survival of the Toads Bufo-Bufo. Oecologia 89: 161-165.

[18] Haas, M., Lukán, M., Kisková, J., Hrehová, Z. 2012. Occurrence of blood parasites and intensity of infection in Prunella modularis in the montane and subalpine zone in the Slovak Carpathians. Acta Parasitol. 57: 221-227.

[19] Harper, E.B., Measey, G.J., Patrick, D.A., Menegn, M., Vonesh, J.R. 2010. Field Guide to the Amphibians of the Eastern Arc Mountains and Coastal Forests of Tanzania and Kenya. pp. 114. Nairobi, Kenya: Camerapix Publishers International.

[20] Hasselquist, D., Östman O., Waldenström, J., Bensch, S. 2007. Temporal patterns of occurrence and transmission of the blood parasite Haemoproteus payevskyi in the great reed warbler (Acrocephalus arundinaceus). J. Ornithol. 148: 401-409.

[21] Hirai, T., Matsui, M. 2002. Feeding ecology of Bufo japonicus formosus from the Montane Region of Kyoto, Japan. J. Herpetol. 36:719-723.

[22] Hyatt, A.D., Gould, A.R., Zupanovic, Z., Cunningham, A.A., Hengstberger, S., Whittington, R.J., Kattenbelt, J., Coupar, B.H. 2000. Comparative studies of piscine and amphibian iridoviruses. Arch. Virol. 145: 301-331. 
[23] Ibrahim, M.M.I. 2008. Helminth infracommunities of the maculated toad Amietophrynus (Bufo) regularis (Anura: Bufonidae) from Ismailia, Egypt. Dis. Aquat. Organ. 82: 19-26.

[24] IUCN 2013. Amphibian Specialist Group. Amietophrynus xeros. IUCN Red List of Threatened Species. Version 2014.3. 〈www.iucnredlist.org>. Downloaded on 01 January 2015.

[25] Kuzmin, Y., Tkach, V.V., Brooks, D.R. 2007. Two new species of Rhabdias (Nematoda: Rhabdiasidae) from the marine toad, Bufo marinus (L.) (Lissamphibia: Anura: Bufonidae), in Central America. J. Parasitol. 93: 159-165.

[26] Leon-Regagnon, V., Martinez-Salazar, E.A., Lazcano-Villareal, D., Rosas-Valdez, R. 2005. Helminth parasites of four species of anurans from Nuevo Leon, Mexico. Southwestern Nat. 50: 251-258.

[27] Luque, J.L., Martins, A.N., Tavares, L.R. 2005. Community structure of metazoan parasites of the yellow Cururu toad, Bufo ictericus (Anura, Bufonidae) from Rio de Janeiro, Brazil. Acta Parasitol. 50: 215-220.

[28] McAllister, C.T., Trauth, S.E., Bursey, C.R. 1995. Parasites of the pickerel frog, Rana palustris (Anura: Ranidae), from the southern part of its range. Southwestern Nat. 40: 111-116.

[29] Melo, F.T.V., Giese, E.G., Furtado, A.P., Soares, M.J., Gonçalves, E.C., Vallinoto, A.R., Santos, J.N. 2011. Lanfrediella amphicirrus gen. nov. sp. nov. Nematotaeniidae (Cestoda: Cyclophyllidea), a tapeworm parasite of Rhinella marina (Linnaeus, 1758) (Amphibia: Bufonidae). Mem. Inst. Oswaldo Cruz, Rio de Janeiro 106: 670-677.

[30] Mohammad, M.K., Al-Moussawi, A.A., Jasim, S.Y. 2010. Helminth Parasites of the Green Toad Bufo viridis Laurenti, 1768 in Baghdad Area, Central Iraq. Egypt. Acad. J. Biolog. Sci. 2: 17-25.

[31] Moravec, F., Barus, F., Rysavy, B. 1987. Some parasitic nematodes, excluding Heterakidae and Pharyngodonidae, from amphibians and reptiles in Egypt. Folia Parasitol. 34: 255-267.

[32] Patterson-Kane, J.C., Eckerlin, R.P., Lyons, E.T., Jewell, M.A. 2001. Strongyloidiasis in a Cope's grey tree frog (Hyla chrysoscelis). J. Zoo. Wildlife Med. 32: 106-110.

[33] Rahman, W.A, Tan, A., Sufina, I. 2008. On the parasitic fauna of two species of anurans collected from Sungai Pinang, Penang Island, Malaysia. Trop. Biomed. 25: 160-165.

[34] Rödel, M.O. 2000. Herpetofauna of West Africa, Vol. I. Amphibians of the West African Savanna. Edition Chimaira, pp. 332. Frankfurt, Germany.

[35] Sanchis, V., Roig, J.M., Carretero, M.A., Roca, V., Llorente, G.A. 2000. Host-parasite Relationships of Zootoca vivipara (Sauria: Lacertidae) in the Pyrenees (North Spain). Folia Parasitol. 47: 118-122.

[36] Santos, V.G.T., Amato, S.B. 2010. Helminth fauna of Rhinella fernandezae (Anura: Bufonidae) from the Rio Grande do Sul Coastland, Brazil: Analysis the parasite community. J. Parasitol. 96: 823-826.

[37] Santos, V.G.T., Amato, S.B., Márcio Borges, M. 2013. Community structure of helminth parasites of the "Cururu" toad, Rhinella icterica (Anura: Bufonidae) from southern Brazil. Parasitol. Res. 112: 1097-1103.

[38] Sulieman, Y., Pengsakul, T., 2015. Non-hemoparasitic protozoa of the subdesert toad, Amietophrynus (Bufo) xeros (Anura: Bufonidae). International Journal of Fauna and Biological Studies 2(4): 89-92. 
[39] Tinsley, R., Stott, L., York, J., Everard, A., Chapple, S., Jackson, J., Vinev, M., Tinsley, M.C. 2012. Acquired immunity protects against helminth infection in a natural host population: long-term field and laboratory evidence. Int. J. Parasitol. 42: 931-938.

[40] Treml, F., Neperený, J., Janová, E., Bandouchová, H., Pikula, J. 2012. Prevalence of antibodies against leptospires in small mammals in relation to age, sex and season. Acta Vet. Brno 81: 97-102.

Table 1: Prevalence, mean intensity (range), and site of infection of helminths in A. xeros toad ( $\mathrm{n}=69)$, from Shendi, Sudan.

\begin{tabular}{lccl} 
Helminth species & Prevalence (\%) & Mean intensity (range) & Site of infection \\
\hline Nematoda & & & \\
Aplectana macintoshii & 91.30 & $20.21(2-55)$ & Large intestine \\
Rhabdias bufonis & 17.40 & $17.33(3-80)$ & Lungs \\
Strongyloides prokopici & 13.04 & $2.44(1-5)$ & Small intestine \\
$\begin{array}{l}\text { Oswaldocruzia } \text { sp. } \\
\text { Trematoda }\end{array}$ & 11.60 & $3.40(2-5)$ & Small intestine \\
Mesocoelium sp. & 18.84 & $44.4(2-150)$ & Small intestine \\
Cestoda & & & \\
Lanfrediella $\mathrm{sp}$. & 20.30 & $3.30(1-8)$ & Small intestine \\
\hline
\end{tabular}

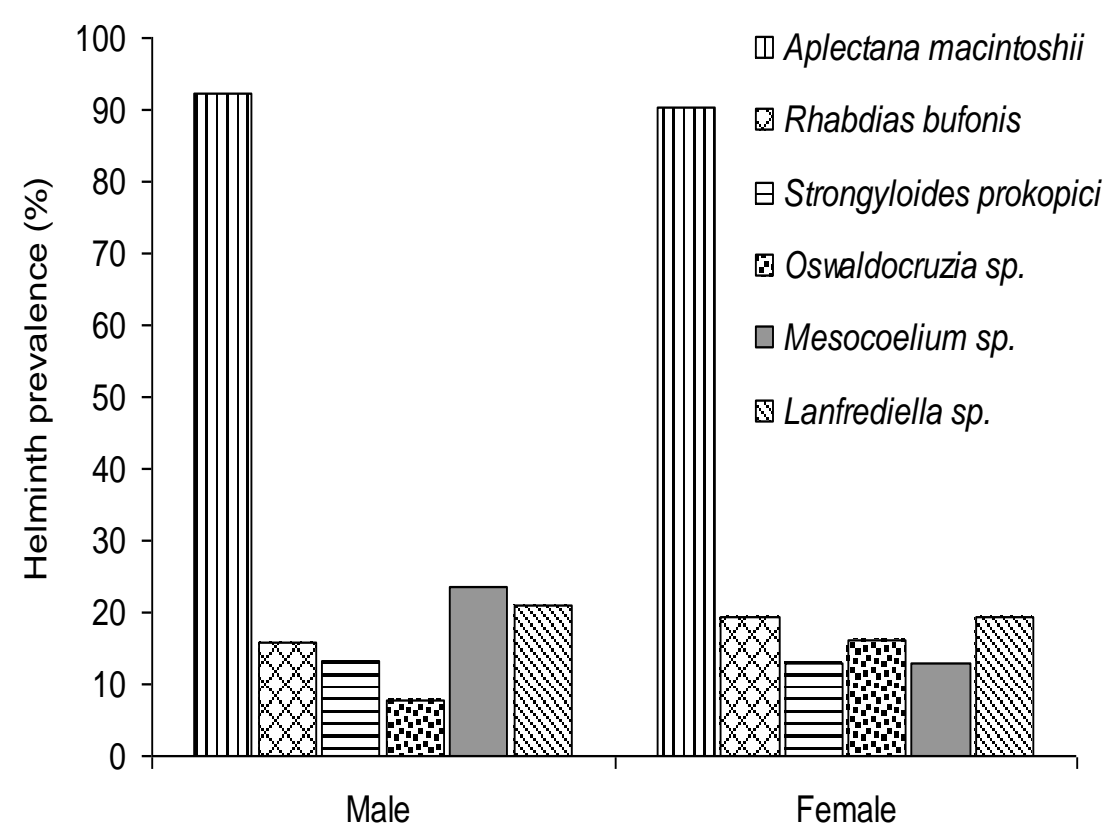

Host gender

Figure 1: Prevalence of helminth infections among A. xeros toads, according to gender, (male: $n$ = 38; female: $n=31$ ). 


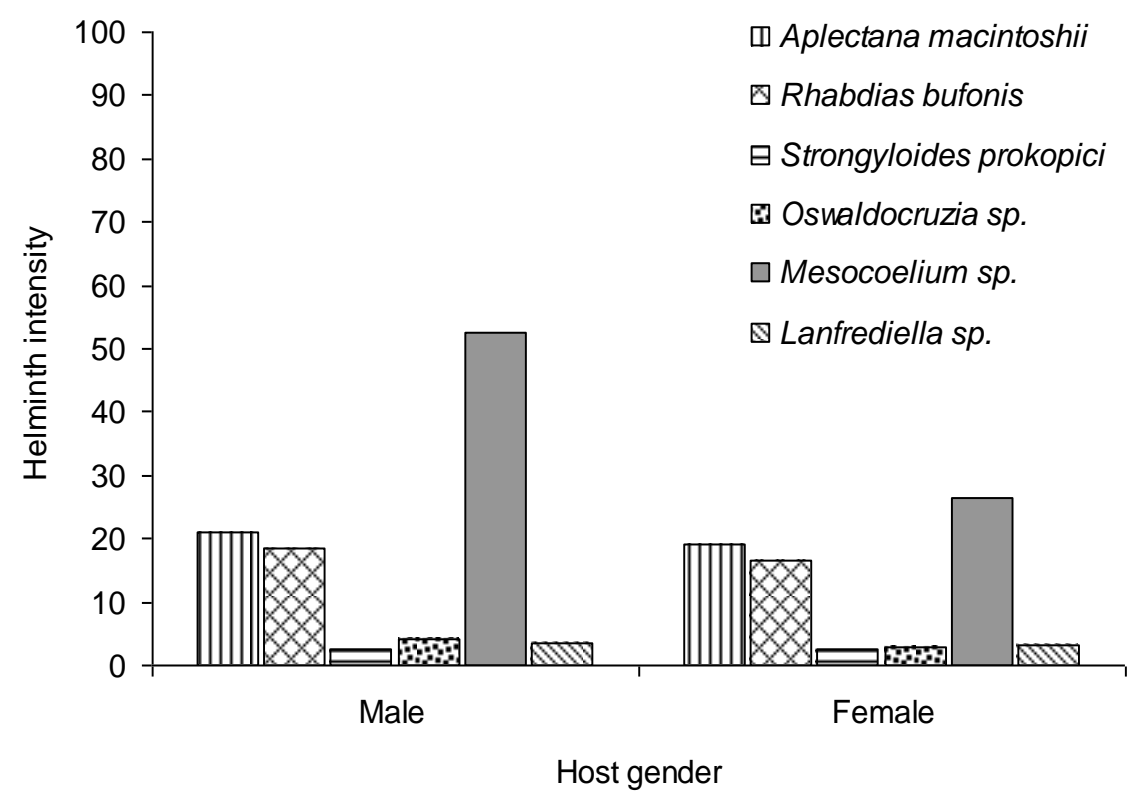

Figure 2: Intensity of helminth infections among A. xeros toads, according to gender, (male: $n$ =38; female: $n=31$ ).

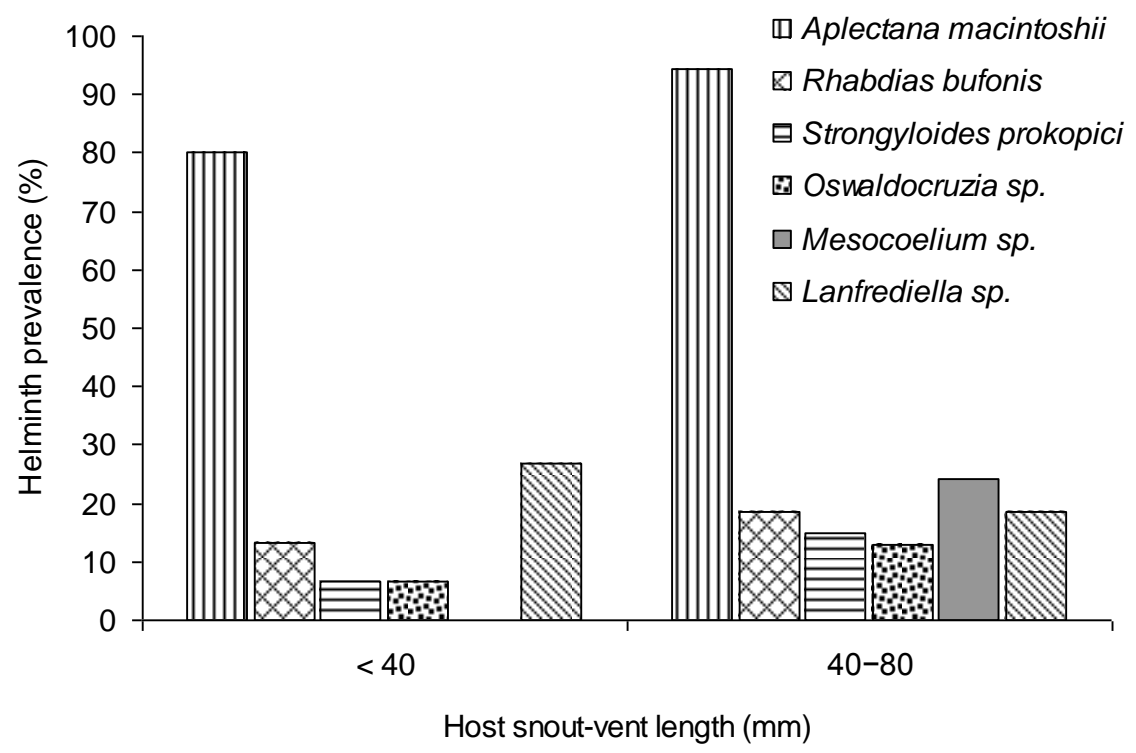

Figure 3: Prevalence of helminth infections among A. xeros toads, according to $S V L$, (< $40 \mathrm{~mm}$ :

$$
n=15 ; 40-80 \mathrm{~mm}: n=54) \text {. }
$$




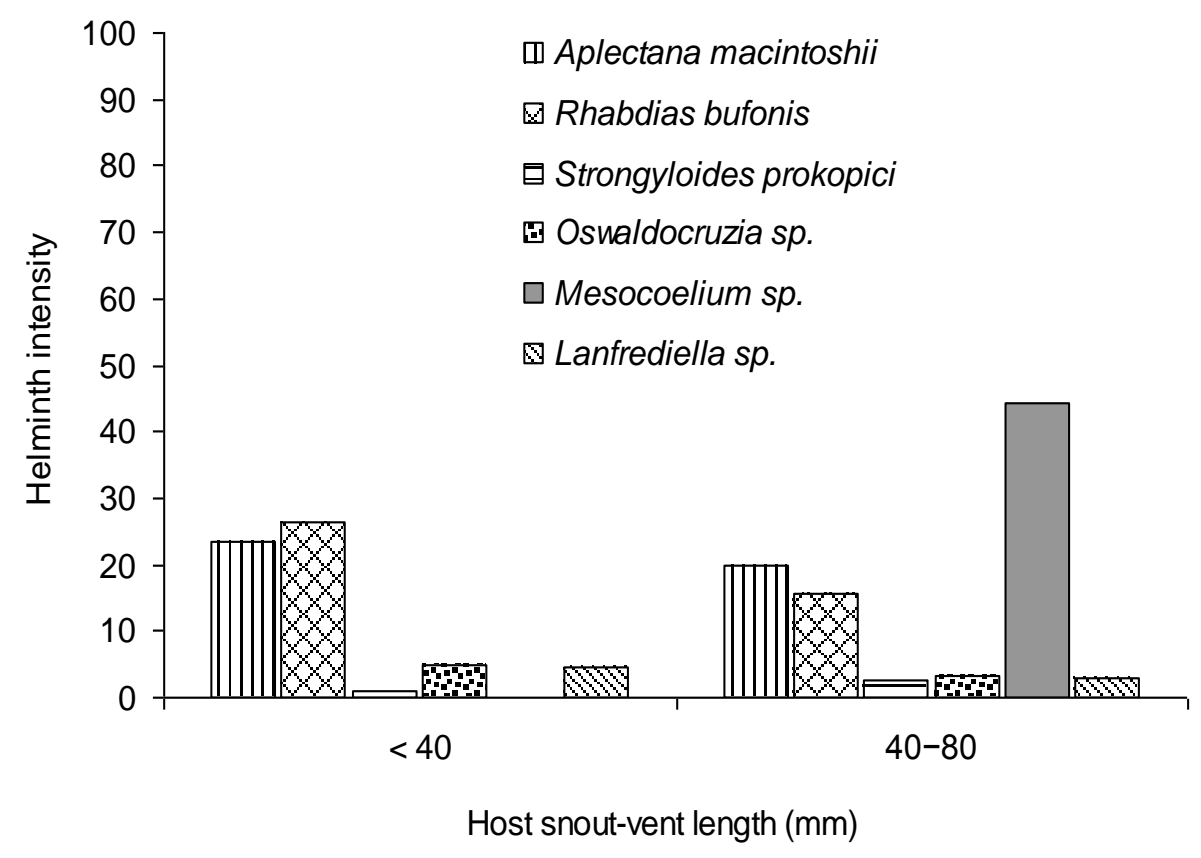

Figure 4: Intensity of helminth infections among A. xeros toads, according to SVL, (<40 mm: $n$ $=15 ; 40-80 \mathrm{~mm}: \mathrm{n}=54)$. 